\title{
The status of ward-based clinical education: the medical students' opinion
}

This article was published in the following Dove Press journal:

Advances in Medical Education and Practice

7 October 2016

Number of times this article has been viewed

Farzana Begum'

Farah Jaffar'

Doa'a Kerwat'

Salma Marouf'

Hiral Rana'

Yasir Ashraf ${ }^{2}$

Bassit Malik²

'Barts and the London School of Medicine and Dentistry, ${ }^{2}$ School of Medicine, Imperial College London, London, UK
Correspondence: Farzana Begum

12 Cox Road, Alresford, Essex, CO7 8EJ, UK

Email begum@smdI2.qmul.ac.uk

\section{Dear editor,}

We read with great interest the article by Jones and Rai, ${ }^{1}$ which researched the views of medical students toward bedside teaching. Students from only four UK medical schools were surveyed and the findings lacked qualitative feedback; hence, as fifth year medical students from Barts and the London School of Medicine and Dentistry and Imperial College London, we express our views on bedside teaching and other resources of clinical education.

Practicing clinical examinations on real patients is commonly viewed as the best way to gain clinical skills. ${ }^{2,3}$ However, the attitudes of medical students toward the role and importance of bedside teaching are changing, shifting from being viewed as a central pole of clinical education to merely an additional, supplementary resource. Perhaps with the decline in the amount of bedside teaching being delivered ${ }^{4}$ and the rise in alternative resources for clinical education, expectations that medical students have for bedside teaching are declining.

Generally, medical students feel they could receive more bedside teaching than they already do. Teaching from time-constrained consultants is limited to weekly timetabled sessions and sometimes ward rounds. Alternatively, junior doctors are approachable and effective teachers of clinical skills; they can relate to medical students and are skillful in a broad range of relevant clinical examinations. This correlates with findings in the research by Jones and Rai; ${ }^{1}$ a greater proportion of more senior medical students identify junior doctors being as good as senior doctors in teaching clinical skills.

There are multiple barriers to clinical education that medical students face on hospital wards. ${ }^{5,6}$ One of the main barriers to bedside learning which Jones and Rai ${ }^{1}$ did not explore is the student's own attitude and motivation. Many students feel they are capable of learning clinical material from senior peers and the Internet, viewing wardbased learning as supplementary teaching of basic skills that they may have already acquired. This is generally the case unless consultants find interesting patients and teach more than the fundamentals in an impromptu, 360-degree learning experience. A shift from timetabled teaching toward 360-degree ward-based teaching not only promotes thinking aloud and diagnostic reasoning by time-constrained clinicians that is beneficial to students, but it provides more opportunity for - and variety in patient based learning. ${ }^{1}$ 
A key factor to motivating medical students to learn on the wards is sign-offs for their log books; this can become the sole reason as to why some students attend placements, distracting them from the essence of clinical teaching as they focus on quantity rather than quality of the clinical examinations they perform. Rather than medical schools using logbooks to monitor performance, they should make ward-based learning less target-driven. Perhaps having mock clinical exams at the end of the placement with feedback is a more effective method of assessing performance, as this would motivate students to learn to a good quality standard rather than practice in quantity.

As the amount of ward-based teaching declines, alternative resources such as peer-led teaching and Internet tutorials have become more popular. As found in research by Haist et al, ${ }^{7}$ peer-led teaching is incredibly valuable when preparing for clinical examination assessments. In our experience, peerled teaching from senior medical students forms the largest source of clinical skills education during medical school. Peer-led teaching is relevant to the needs of medical students and breaks down hierarchical barriers, empowering students with greater confidence and motivation to learn. Medical schools should encourage peer-led teaching, improving students' abilities to receive and deliver clinical education.

The research by Jones and $\mathrm{Rai}^{1}$ did not report the use of e-learning and video tutorials on Internet sites such as "geekymedics.com"8 as preferred methods of preparing for assessment on clinical examinations. From experience, such sites are great outlets for learning step-by-step clinical skills and relevant pathology in the students' own time. Video tutorials are becoming more and more popular and are relied upon by medical students. Further research needs to be carried out to observe whether such forms of rote learning without real patient contact, affect the clinical and diagnostic skills of the future generation of doctors.

In conclusion, the decline in amount of bedside teaching being delivered, as well as the rise in popularity of alternative resources for clinical education has impacted the expectations and attitudes of medical students with regards to clinical education on the wards. Currently, in addition to the decline in delivery of ward-based teaching, a significant amount of students feel they can learn clinical skills elsewhere and are target-driven when they attend placements, hindering the quality of learning on the wards.

\section{Disclosure}

The authors report no conflicts of interest in this communication.

\section{References}

1. Jones P, Rai B. The status of bedside teaching in the United Kingdom: the student perspective. Adv Med Educ Pract. 2015;6:421-429.

2. Peters $M$, ten Cate $O$. Bedside teaching in medical education: a literature review. Perspect Med Educ. 2013;3(2):76-88.

3. K Ahmed Mel-B. What is happening to bedside clinical teaching? Med Educ. 2002;36(12):1185-1188.

4. Crumlish CM, Yialamas MA, McMahon GT. Quantification of bedside teaching by an academic hospitalist group. J Hosp Med. 2009;4(5):304-307.

5. Nair BR, Coughlan JL, Hensley MJ. Impediments to bed-side teaching. Med Educ. 1998;32(2):159-162.

6. Cooper D, Beswick W, Whelan G. Intensive bedside teaching of physical examination to medical undergraduates: evaluation including the effect of group size. Med Educ. 1983;17(5):311-315.

7. Haist SA, Wilson JF, Fosson SE, Brigham NL. Are fourth-year medical students effective teachers of the physical examination to first-year medical students? J Gen Intern Med. 1997;12(3):177-181.

8. Geeky Medics | free medical student revision notes \& OSCE guides [homepage on the Internet]. Geeky Medics; 2016 [cited August 21, 2016]. Available from: http://geekymedics.com. Accessed September 14, 2016. 


\section{Authors' reply \\ Patrick Jones \\ Bhavan Prasad Rai \\ Department of Surgery, Ninewells Hospital, Dundee, UK}

Correspondence: Patrick Jones

Department of Surgery, Ninewells Hospital, Ninewells Avenue, Dundee, DDI 9SY, UK

Tel +44 I382 554010

Fax +44 I382 632327

Email patrick.jones I@nhs.net

\section{Dear editor,}

The authors thank Begum et al for their learned views on bedside teaching and qualitative feedback on our recent paper. ${ }^{1}$ Indeed, it is deeply encouraging to hear from doctors of tomorrow who are passionate about this tradition and clearly recognize its importance. Today's challenges facing medical school curricula are constantly evolving. Time will tell if other elements such as the recent "Brexit" result will have an impact on the future learning of medical students in the UK.

For surgeons in training, simulation and intensive "boot camp" style programs have formed an integral part of the solution to difficulties caused by working time directives. ${ }^{2}$
They allow for acquisition and consideration of core skills in an accelerated manner. We should expect this to be likely translated to an undergraduate level and modified accordingly. Certainly, our previous research has identified at present, newly qualified doctors are left under-confident at key practical competencies such as urinary catheterization. ${ }^{3}$

The future place of bedside teaching is not known but junior trainees are in a pivotal position to enable its importance to be preserved. While educators must provide sufficient opportunities for bedside teaching, students must be inspired so that they seek independently these opportunities in the clinical environment.

\section{Disclosure}

The authors report no conflicts of interest in this communication.

\section{References}

1. Jones P, Rai B. The status of bedside teaching in the United Kingdom: the student perspective. Adv Med Educ Pract. 2015;6:421-429.

2. Rai BP, Stolzenburg JU, Healy S, et al. Preliminary validation of Thiel embalmed cadavers for laparoscopic radical nephrectomy. $J$ Endourol. 2015;29(5):595-603.

3. Jones P, Raj BP, Qazi HA, Somani BK, Nabi G. Perception, career choice and self-efficacy of UK medical students and junior doctors in urology. Can Urol Assoc J. 2015;9(9-10):E573-E578.

Dove Medical Press encourages responsible, free and frank academic debate. The content of the Advances in Medical Education and Practice 'letters to the editor' section does not necessarily represent the views of Dove Medical Press, its officers, agents, employees, related entities or the Advances in Medical Education and Practice editors. While all reasonable steps have been taken to confirm the content of each letter, Dove Medical Press accepts no liability in respect of the content of any letter, nor is it responsible for the content and accuracy of any letter to the editor.

\section{Publish your work in this journal}

Advances in Medical Education and Practice is an international, peerreviewed, open access journal that aims to present and publish research on Medical Education covering medical, dental, nursing and allied health care professional education. The journal covers undergraduate education, postgraduate training and continuing medical education including emerging trends and innovative models linking education, research, and health care services. The manuscript management system is completely online and includes a very quick and fair peer-review system. Visit http://www.dovepress.com/testimonials.php to read real quotes from published authors.

Submit your manuscript here: http://www.dovepress.com/advances-in-medical-education-and-practice-journal 